\title{
TOLERANT HONEY BEE COLONIES TO INFECTION BY AMERICAN FOUL BROOD DISEASE USING AROMATIC OILS
}

\author{
MAHMOUD E. ZAKARIA
}

Plant Protection Research Institute, ARC, Dokki, Giza, Egypt

(Manuscript received $1^{\text {st }}$ March 2011)

\begin{abstract}
Tolerant honey bee colonies to American foul brood disease (AFB) using the feeding on the aromatic oils added to sugar syrup before (AFB) bacterial artificially infection were studied. clove, cumin and citrus oils showed different immunity responsiveness against (AFB) disease as oil phenolic components as different. The bacterial spores can't be able to germinate in the haemolymph of honey bee larvae treated with the clove oil which distinguishes by encompass large numbers of the phenolic compounds participate together in the tolerant system against the bacterial infection and persist long period doesn't decrease than seven weeks with higher phagocyte cells were detected in the bee larval haemolymph.
\end{abstract}

\section{INTRODUCTION}

American foul brood disease (AFB) caused by the bacteria Paenibacillus larvae considered one of the important honey bee diseases infected honey bee colonies in many countries in the world. Bacterial pathogen spores are ingested by a honey bee larva and germinate in the midgut. The rod-shaped vegetative forms penetrate the larval intestinal tissue and start multiplying rapidly, sporulates and multiplies efficiently in the haemolymph, finally kills them (Gende et al., 2008). The prevention and controlling of this disease have different features as the spores can remain viable for long years and survive under adverse environmental conditions (Matheson and Reid 1992). The paper looks at the potential use of aromatic oils in the tolerance to the pathogen infections which is in preoccupy the entomological scientists. Despite of the aromatic oil doesn't contains hypericin or pseudohypericin. It contains Quercetin, a Pentahydroxy flavone. It having in vitro anti-microbial properties indicates that the aromatic oil could be an interesting new avenue as antiseptic (Jane Buckle,2002). Clove oil is used in limited amounts in food products as a fragrant, flavoring agent, and antiseptic. Black cumin seed aromatic oil commonly known as black cumin seed oil or black seed oil, are used in folk (herbal) medicine all over the world for the treatment and prevention of a number of diseases and conditions that include asthma, diarrhoea and dyslipidaemia, anti-inflammatory, analgesic, antipyretic, antimicrobial, antineoplastic activity with a very low degree of toxicity (Ali and Blunden 2003). Eight 
fatty acids (undecanoic, lauric [dodecanoic], myristic, myristoleic, ricinoleic, ricinelaidic, homo-y-linolenic and 13,16,19-docosatrienoic acids) can be inhibit the growth of Melissococcus plutonius cultures, could protect larvae from developing (EFB) (Giersch et al., 2009). This study is aimed to investigate the effect of treated honey bee colonies infected by (AFB) using some aromatic oils on the disease infection level and to how degree the tolerant probability.

\section{MATERIALS AND METHODS}

Twelve honey bee colonies from Carniolian hybrid were divided into four main groups. Three groups were specialized for artificially infection with (AFB), while the rest four group was considered as control.

\section{I- The extraction oils and doses}

The extraction of clove oil (Syzygium aromaticum), black cumin oil (Nigella sativa Linn.) and citrus oils (Citrus aurantium Risso and Citrus lemon, $\mathrm{V}: \mathrm{V}$ ) were used as a suspension by mixing $1 \mathrm{ml}$. of the crude oil with $10 \mathrm{mg}$. of Triton- $X$ (emulsifier) added to $200 \mathrm{ml}$. of the sugar solution ( 2 sugar: 1 water). Three of the colonies groups were fed weekly for 6 weeks consecutively on one of the aromatic oils. Last four group was fed only on the sugar solution as control.

\section{II- Isolation and preparation of the bacterium suspension}

The dead scales of infected bee larvae were used to isolate the bacterium spores. The spores suspension of the micro-organism (Paenibacillus larvae subsp. larvae) was prepared as the method of (Shimanuki and Knox, 1991) in the Laboratory of Agric. Microbiology, Fac. Agric., Cairo Univ., Giza, Egypt. The bacterial suspension was prepared by immersion a pure colony of Paenibacillus larvae in $10 \mathrm{ml}$ of sterile distilled water (to get a higher concentration of the bacterial spores with a final concentration $10^{6} /$ spoes $/ 1 \mathrm{ml}$ ) and stored at $4^{\circ} \mathrm{C} . \quad 1 \mathrm{ml}$ of the suspension was added to $200 \mathrm{ml}$ of the sugar solution (2 sugar: 1 water ) (w:w). The commingle was sprayed between bee combs ( $5 \mathrm{ml} /$ colony ) in the tested three bee groups as soon as last treatment by the aromatic oils was ending. This treatments were repeated three times intervals / one week.

\section{III - Determine of tolerant bee colonies}

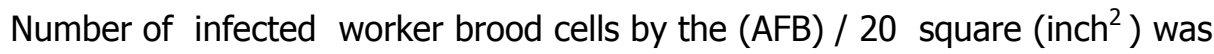
determined started of 29/7/2010 every 7 days tell end tolerant period of honey bee colonies which recorded at 9/9/2010. 


\section{V- Preparation of the haemolymph films}

To investigate effect of the aromatic oils on the haemocytes of the haemolymph of five days old larvae tolerant (represented clove treatment) and non-tolerant (as control). The blood films were carried out according to method of Gilliam and Shimanuki (1971).

\section{VI- HPLC identification of phenolic compounds in the Aromatic oils}

High Performance Liquid Chromatography (HPLC) apparatus was used to determine the phenolic compounds of the tested aromatic oils based on the method of (Oszmianski and Lee,1990).

\section{RESULTS AND DISCUSSION}

\section{I- Effect of the aromatic oils on tolerant honey bee colonies to the (AFB) disease}

In general the colonies treated with the aromatic oils demonstrated clearly decreases of (AFB) diagnosis during the first three weeks of treatments. The effective differences against the disease between the aromatic oils were clearly detected began of the $4^{\text {th }}$ week until end of treatments ( Table 1 and Fig.1 ).

1- Clove oil showed more tolerant to (AFB) disease for long period reached to 7 weeks after the bacterial sprayed, whereas infection level wasn't increase than $1 / 20$ inch $^{2}$ at the last of tolerant period.

2- Treatments with cumin oil showed proportional tolerant to (AFB) infection reached to 3 weeks. then decreased tell the $7^{\text {th }}$ week.

3- Honey bee colonies treated with citrus oil displayed weak tolerant to (AFB) disease reached only to 3 weeks from the treatment quickly downfall consider of the $4^{\text {th }}$ week resemble the lower tolerant level between all oil treatments and control one.

4-The control treatment showed the faster infection level particular at the $2^{\text {nd }}$ week. 
Table 1. Effect of the aromatic oils on the infection level of (AFB) disease (inch ${ }^{2}$ ).

\begin{tabular}{|c|c|c|c|c|}
\hline Date & $\begin{array}{c}\text { Control } \\
\text { Mean } \pm \text { Sd }\end{array}$ & $\begin{array}{c}\text { Clove oil } \\
\text { Mean } \pm \text { Sd }\end{array}$ & $\begin{array}{c}\text { Cumin oil } \\
\text { Mean } \pm \text { Sd }\end{array}$ & $\begin{array}{c}\text { Citrus oils } \\
\text { Mean } \pm \text { Sd }\end{array}$ \\
\hline $29 / 7 / 2009$ & $0 \pm 3.915$ & $0 \pm 0.4780$ & $0 \pm 3.7614$ & $0 \pm 7.1083$ \\
\hline $5 / 8 /$ & $12 \pm 3.915$ & $0 \pm 0.4780$ & $1 \pm 3.7614$ & $2 \pm 7.1083$ \\
\hline $12 / 8 /$ & $5 \pm 3.915$ & $0 \pm 0.4780$ & $1 \pm 3.7614$ & $2 \pm 7.1083$ \\
\hline $19 / 8$ & $5 \pm 3.915$ & $0 \pm 0.4780$ & $5.33 \pm 3.761$ & $15 \pm 7.1083$ \\
\hline $26 / 8 /$ & $10 \pm 3.915$ & $0 \pm 0.4780$ & $5 \pm 3.7614$ & $15 \pm 7.1083$ \\
\hline $2 / 9 /$ & $5.33 \pm 3.915$ & $0 \pm 0.4780$ & $5 \pm 3.7614$ & $10 \pm 7.1083$ \\
\hline $9 / 9 /$ & $10 \pm 3.915$ & $1 \pm 0.4780$ & $10 \pm 3.7614$ & $18 \pm 7.1083$ \\
\hline $\mathrm{LSD}_{0.05 \%}$ & 6.8090 & 0.1428 & 3.7614 & 8.8571 \\
\hline
\end{tabular}

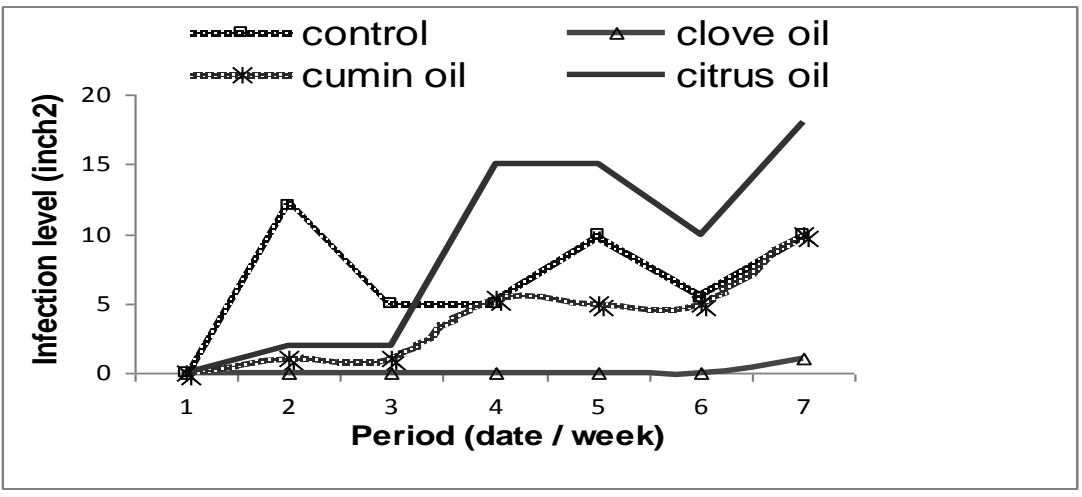

Fig. 1. Infection levels of the (AFB) disease in honey bee colonies using aromatic oils treatment.

\section{II -Blood picture of larval honey bee workers}

The blood cells of the five days old of honey bee larvae tolerant (represented clove treatment) and non-tolerant (as control) to infection by (AFB) disease were recorded and photographed. Clearly changes in the haemocytes percentage were detected (Table 2 and Figs. 2, 4,5,6).

Honey bee colonies treated with clove oils showed higher phagocyte cells percentage. The Macronucleocyte cells recorded (9.19\%) in comparison with non treated colonies $(0.95 \%)$. The Macronucleocyte cells in the infection by the (AFB) showed changing in the nuclei cytoplasm indicated secondary virus infection in non tolerant colonies (Fig.3). The Micronucleocyte cells realize (7.28\%) in comparison with controls ( $2.61 \%$ ) with thickness in their outer edges were recorded (Fig. 4). As well as the Oenocytoids (Fig.5). Despite of there were densities of the Paenibacillus spores in the haemolymph of larval bee workers treated of the clove oils, there were not any vegetative cells of the pathogen.

Dash cells (Fig.2) which rarely found in the haemolymph of healthy larval honey bees $(0.94 \%)$ were presented with higher percentage $(6.59 \%)$ with clove oil (Table 2 ). New phagocyte cells as plasmatocytes with treatment by the clove oil were displayed with few percentage (Fig.6). 
Table 2. Blood picture of larval worker honey bees in tolerant (represented clove treatment) and non-tolerant (as control) to infection by (AFB) disease.

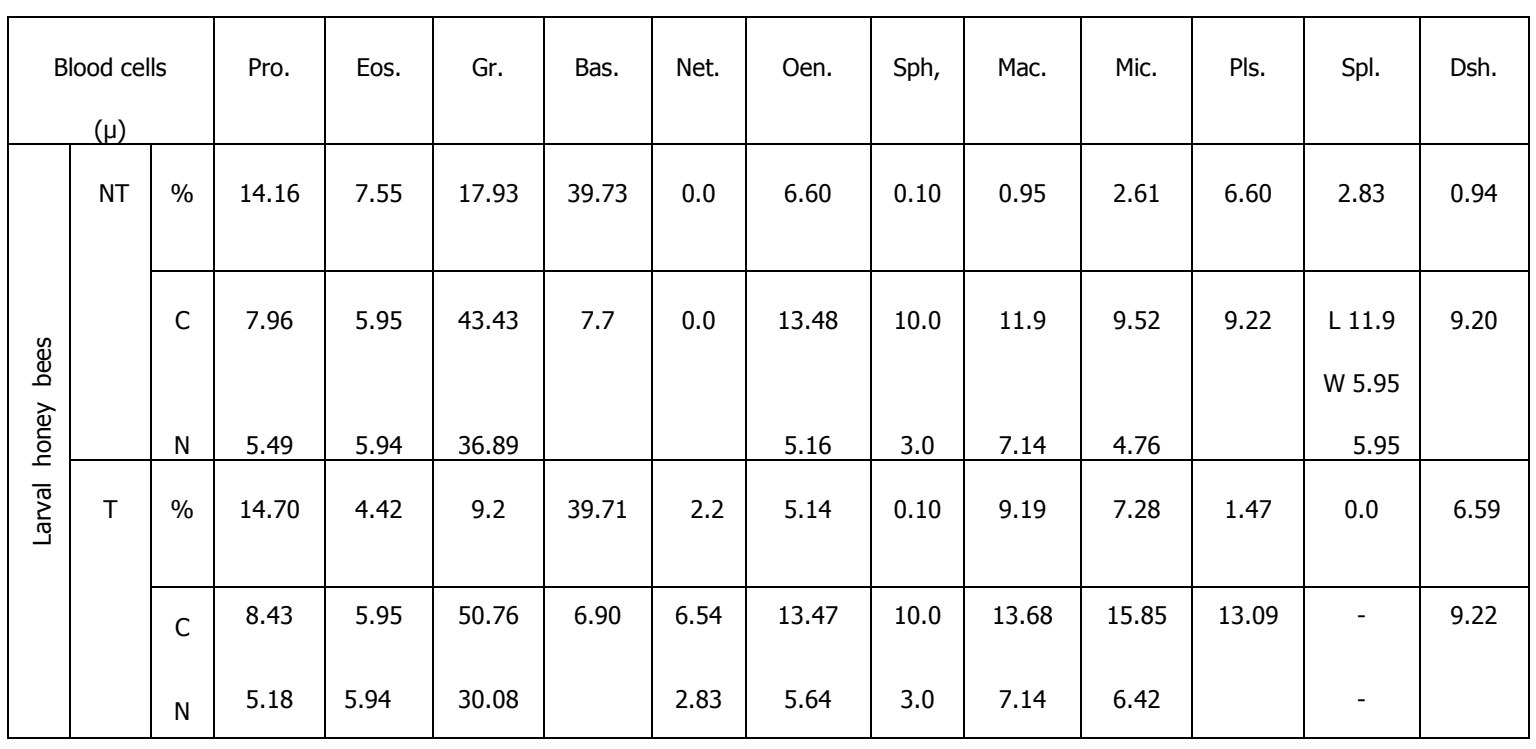

NT :Non- tolerant bee larvae. T: Tolerant bee larvae. C: cell measure.

N. : Nucleus diameter. L: Length. W: Width.
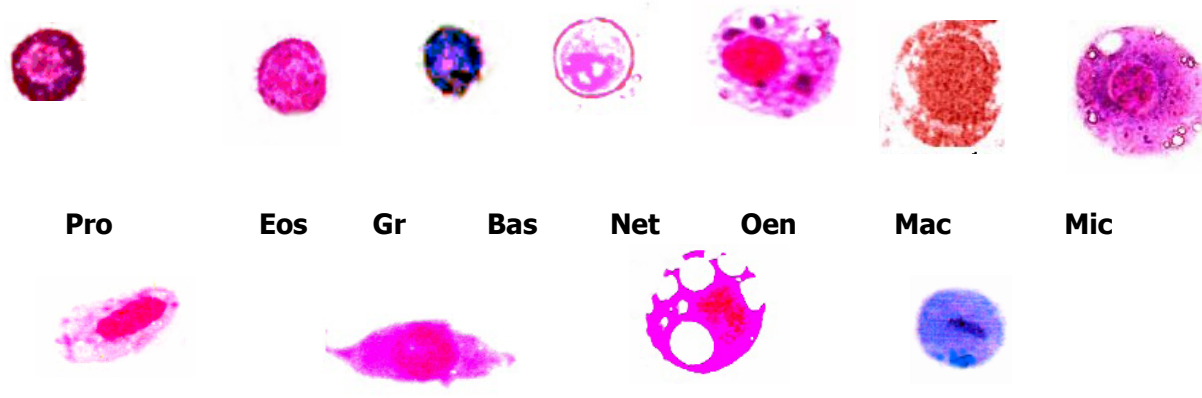

Mac

Mic

Pls

Spl

Sph

Dsh

Fig.2: Blood cells of non treating larval honey bees of the $5^{\text {th }}$ instars.

Pro:Proleucocyte. Eos: Eosinophil. Gr: Granulocyte. Bas.: Basophil.

Net: Neutrophil. Oen.: Oenocytoid. Mac.:Macronucleocyte. Mic.:Micronucleocyte.

PIs.:Plasmatocyte. Spl : Spindle shaped cell. Sph: Spherulocyte. Dsh: Dash cell. $(x-1000)$. 


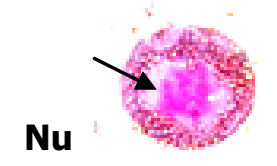

Fig.3

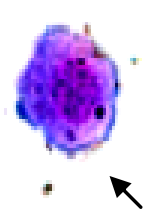

Fig.4

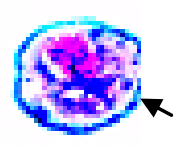

Fig.5

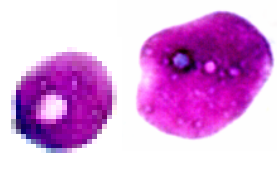

Fig.6

Fig.3: Macronucleocyte cell in the infection by the (AFB) showing change in the nuclei cytoplasm $(\mathrm{Nu})$ indicted secondary virus infection $(x-1000)$.

Fig.4: Micronucleocyte cell showed coarsen in some outer regions with the clove oil treatment $(x-1000)$.

Fig.5: Oenocytiods in the treated with the clove oil showed thickness in their outer edge (arrow) $(x-1000)$.

Fig.6: New phagocyte cells as plasmatocytes were displayed with treatment by the black cumin oil with lowest percentage $(x-1000)$.

\section{III-Identification of phenolic compounds in the aromatic oils by HPLC}

HPLC apparatus was used to identify the phenolic compounds presented in the tested oils which may be contributed in the tolerant process against (AFB) disease. 14 phenolic compounds were detected in the clove oil, while in the cumin oil 10 compounds were recorded. Whereas two compounds in the citrus oils were recorded as shown in Table (3) and Figs. $(7,8,9)$.

From the obtained results it could be concluded that honey bee colonies treated with clove oil indicated the higher tolerant against (AFB) disease reached to 7 weeks. This may be due to the phenolic compounds which prevent the spores of germination in the larval bees or inhibited the spore toxins particularly the active ingredients. Pyrogallic acid, Parahydroxy benzoic, Caffic acid, Salicylic acid, Myricetin, 3.3-Dimethoxybenzyl Alchohol, Coumarine, Vanillin and Quercetin were detected in the clove oil not found in the other tested oils. They may be participate together in the tolerant system against bacterial growth. Quercetin *2-(3,4dihydroxyphenyl)3,5,7-trihdroxy-chromen-4-one resemble $(0.024 \% / \mathrm{mg} / 100 \mathrm{mg})$ have an antimicrobial activity. Clove oil have also anti-microbial properties (inhibitory concentration $=<1$ $\mu \mathrm{g} / \mathrm{mL}$ ) in the vitro (Jane Buckle, 2002). Synchronism that with presence higher percentage of the phagocyte cells (Table 2). The cumin oil treatment showed low tolerant to the infection disease that may be due to that oil phenolic compounds 
not contains any effective groups as those found in the clove oil. Citrus oil treatment showed higher infection level between other tested aromatic oils and control one reached to $15 / 20$ inch $^{2}$ of the bee brood area began of the $4^{\text {th }}$ weeks. That may be due to the lowest values of the phenolic compounds which not given any protection to bacterial inhibition growth. Guan et. al., (2007) reported that clove oil contains twenty three compounds play together important role in the bacterial inhibition growth, although the composition of the clove oil extracted by different methods is mostly similar, may relative concentration of the identified compounds is apparently different. The Eugenol compound (Eugenia aromaticum) is a member of the phenylpropanoids class of chemical compounds. It is a clear to pale yellow oily liquid extract from certain aromatic oils especially from clove. It resemble lower quantity $(0.026300 \mathrm{mg} / 100 \mathrm{mg})$ of the clove oil and $(7.797 \mathrm{mg} / 100 \mathrm{mg})$ in the citrus oil and not found in the cumin oil. In spite of large amount of it found in the citrus oil, may it not given any protection from (AFB) infection, indicated that Eugenol compound not alone can be inhibit the bacterial growth. Bensky, et al. (2004) reported that Eugenol compound responsible for most of the characteristic aroma of cloves. Other important aromatic oil constituents of clove oil include acetyl eugenol, betacaryophyllene and vanillin, crategolic acid, tannins, gallotannic acid, methyl salicylate (painkiller), the flavonoids Eugenin, Kaempferol, Rhamnetin, and Eugenitin, Triterpenoids like Oleanolic acid, Stigmasterol and Campesterol, and several sesquiterpenes (Right and Payne 1962). Hashish, (2008) found two protection months to honey bee colonies treated with clove oil against (AFB) disease. He used also 4 antibiotics and 8 natural materials for inhibition of Paenibacillus larvae in the laboratory. Cinnamon oil came in the first arrange followed by clove oil then Peppermint oil. Riessberger et al., (2001) found that vegetative forms of spores of the (AFB) penetrate the larva's intestinal tissue and start rapidly multiplying, finally kills the larva. The midgut extract from winter bees and worker-aged bees of different colonies almost completely inhibit growth of the vegetative stage of Paenibacillus. larvae larvae and suppressed the germination of spores. The inhibiting substance or substances from the adult midgut are very temperature stable, they still show about $60 \%$ of their growth-inhibiting capacity against this bacterium after $15 \mathrm{~min}$. at $125^{\circ} \mathrm{C}$. This substances can be resemble that those found in the clove (Sysygium aromaticum). Pourmortazavi et al., (2005) identified $y$-terpinene (37.98\%), Cuminaldehyde (11.48\%) and $a$-methyl-benzenemethanol $(25.55 \%)$ the major compounds in the black cumin seed oil using fluid extraction (SFE). While Arici et al., (2007) extracted the following compounds in the same oil, Miristic C14, Miristic C14, Palmitic C16, Palmitoleic C16, Margaric C17, Heptadesenoic C17, Stearic C18, Oleic 
C18, Oleic C18, Linoleic C18, Linoleic C18, Arachidic C20, Behenic C22 and Dokosadienoic C22. Plant oils including clove (60\% to $90 \%$ ) is Eugenol (4-allyl-2methoxyphenol) my be used in livestock to inhibit microbial fermentation in waste products. Clove oil may be found in high concentration licorice (glycyrrhizin) products to prevent gel formation in an aqueous solution. Eugenol, a constituent of clove, has been used for analgesic, local anesthetic, anti-inflammatory and antibacterial effects. Forsgren et al., (2010) thought that strongly lactic acid bacteria linked to the honey bee stomach have important implications for honey bee pathology in general and for (AFB) tolerance in particular.

Table 3. Phenolic compounds of clove, cumin and citrus oils.

\begin{tabular}{|c|c|c|c|c|}
\hline \multirow{2}{*}{\multicolumn{2}{|c|}{ Phenolic compounds }} & \multicolumn{3}{|c|}{ Aromatic oils ( $\mathrm{mg} / 100 \mathrm{mg})$} \\
\hline & & \multirow{2}{*}{$\begin{array}{c}\text { Clove } \\
0.087200 \\
\end{array}$} & \multirow{2}{*}{$\begin{array}{c}\text { Cumin } \\
0.000000 \\
\end{array}$} & \multirow{2}{*}{\begin{tabular}{|c|} 
Citrus \\
0.000000 \\
\end{tabular}} \\
\hline Pyrogallic acid - *benzene-1,2,3-triol & $\mathrm{C}_{6} \mathrm{H}_{6} \mathrm{O}_{3}$ & & & \\
\hline Parahydroxy benzoic -*4-Hydroxybenzoic Acid & $\mathrm{C}_{7} \mathrm{H}_{6} \mathrm{O}_{3}$ & 0.000294 & 0.000000 & 0.000000 \\
\hline $\begin{array}{l}\text { Caffic acid *3-(3,4-Dihydroxyphenyl)propo-2- } \\
\text { Enoic Acid }\end{array}$ & $\mathrm{C}_{9} \mathrm{H}_{8} \mathrm{O}_{4}$ & 0.005458 & 0.000000 & 0.000000 \\
\hline Salicylic acid *2- Hydroxybenzoic Acid & $\mathrm{C}_{7} \mathrm{H}_{6} \mathrm{O}_{3}$ & 0.016500 & 0.000000 & 0.000000 \\
\hline $\begin{array}{l}\text { Myricetin 3,5,7-Trihydroxy-2-(3,4,5- } \\
\text { trihydroxyphenyl)- 4-chromenone }\end{array}$ & $\mathrm{C}_{15} \mathrm{H}_{10} \mathrm{O}_{8}$ & 0.006689 & 0.000000 & 0.000000 \\
\hline $\begin{array}{l}\text { 3.3-Dimethoxybenzyl Alchohol } \\
*(3,5 \text {-Dimethoxyphenyl)Methanol }\end{array}$ & $\mathrm{C}_{9} \mathrm{H}_{2} \mathrm{O}_{3}$ & 0.373250 & 0.000000 & 0.000000 \\
\hline Coumarine $*$ Chromen-2-one & $\mathrm{C}_{9} \mathrm{H}_{6} \mathrm{O}_{2}$ & 0.043000 & 0.000000 & 0.000000 \\
\hline $\begin{array}{l}\text { Daidzin *7-Hydroxy-3-(4- } \\
\text { Hydroxyphenyl)Chromen-4-One }\end{array}$ & $\mathrm{C}_{15} \mathrm{H}_{10} \mathrm{O}_{4}$ & 0.001612 & 0.013559 & 0.000000 \\
\hline Eugenol $* 2$-methoxy-4-propo-2-enyl-phenol & $\mathrm{C}_{10} \mathrm{H}_{12} \mathrm{O}_{12}$ & 0.026300 & 0.000000 & 7.797000 \\
\hline $\begin{array}{l}\text { Pinocembrin *2S)-5,7-dihdroxy-2-phenyl- } \\
\text { chroman-4-one }\end{array}$ & $\mathrm{C}_{15} \mathrm{H}_{12} \mathrm{O}_{4}$ & 0.111900 & 3.026800 & 0.000000 \\
\hline $\begin{array}{l}\text { Pinostrobin } * 5,7 \text {-dihidroxy-2=phenyl- } \\
\text { chroman-4-one }\end{array}$ & $\mathrm{C}_{15} \mathrm{H}_{12} \mathrm{O}_{4}$ & 0.033400 & 0.033860 & 0.000000 \\
\hline Vanillin *4-Hydroxy-3-Methoxy-Benzaldehyde & $\mathrm{C}_{8} \mathrm{H}_{8} \mathrm{O}_{3}$ & 0.002699 & 0.000000 & 0.000000 \\
\hline $\begin{array}{l}\text { Quercetin *2-(3,4dihydroxyphenyl)-3,5,7- } \\
\text { trihdroxy-chromen-4-one. }\end{array}$ & $\mathrm{C}_{15} \mathrm{H}_{10} \mathrm{O}_{7}$ & 0.024000 & 0.000000 & 0.000000 \\
\hline $\begin{array}{l}\text { Luteolin 2- (3,4-Dihydroxyphenyl)- 5,7- } \\
\text { dihydroxy-4-chromenone }\end{array}$ & $\mathrm{C}_{15} \mathrm{H}_{10} \mathrm{O}_{6}$ & 2.616000 & 0.036300 & 0.000000 \\
\hline $\begin{array}{l}\text { Ferulic Acid *3-(4-Hydroxy-3-Methoxy-Phenyl- } \\
\text { 2-Enoic Acid }\end{array}$ & $\mathrm{C}_{10} \mathrm{H}_{10} \mathrm{O}_{3}$ & 0.000000 & 1.074000 & 0.000000 \\
\hline Retin & $\mathrm{C}_{20} \mathrm{H}_{28} \mathrm{O}_{2}$ & 0.000000 & 0.018770 & 0.000000 \\
\hline $\begin{array}{l}\text { Genistin *5,7-Dihdroxy-3-(4- } \\
\text { Hydroxyphenyl)Chromen-One }\end{array}$ & $\mathrm{C}_{15} \mathrm{H}_{10} \mathrm{O}_{5}$ & 0.000000 & 0.036890 & 0.0647560 \\
\hline $\begin{array}{l}\text { 3.5 Dihydroxy Isoflavone*3,5-Dihydroxy-3-(4- } \\
\text { Hydroxyphenyl)Chromen-4-One }\end{array}$ & $\mathrm{C}_{15} \mathrm{H}_{10} \mathrm{O}_{5}$ & 0.000000 & 0.003920 & 0.000000 \\
\hline $\begin{array}{l}\text { P-Coumaric Acid Anhydride } \\
\text { *3-(-4-hydroxyphenyl)-2-proponic acid }\end{array}$ & $\mathrm{C}_{9} \mathrm{H}_{8} \mathrm{O}_{3}$ & 0.000000 & 0.015280 & 0.000000 \\
\hline 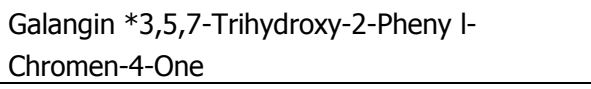 & $\mathrm{C}_{15} \mathrm{H}_{10} \mathrm{O}_{5}$ & 0.000000 & 0.975700 & 0.000000 \\
\hline Total peak area & & 4322567 & 21599909 & 21599909 \\
\hline
\end{tabular}




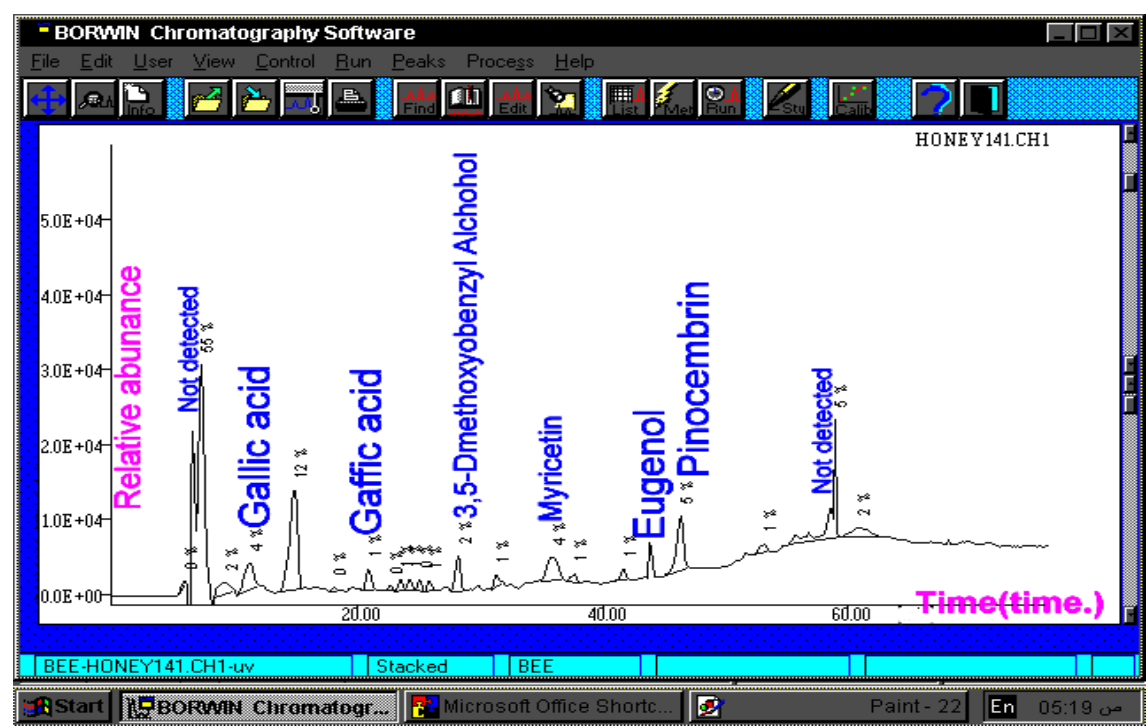

Fig. 7 : Phenolic compounds of the clove oil.

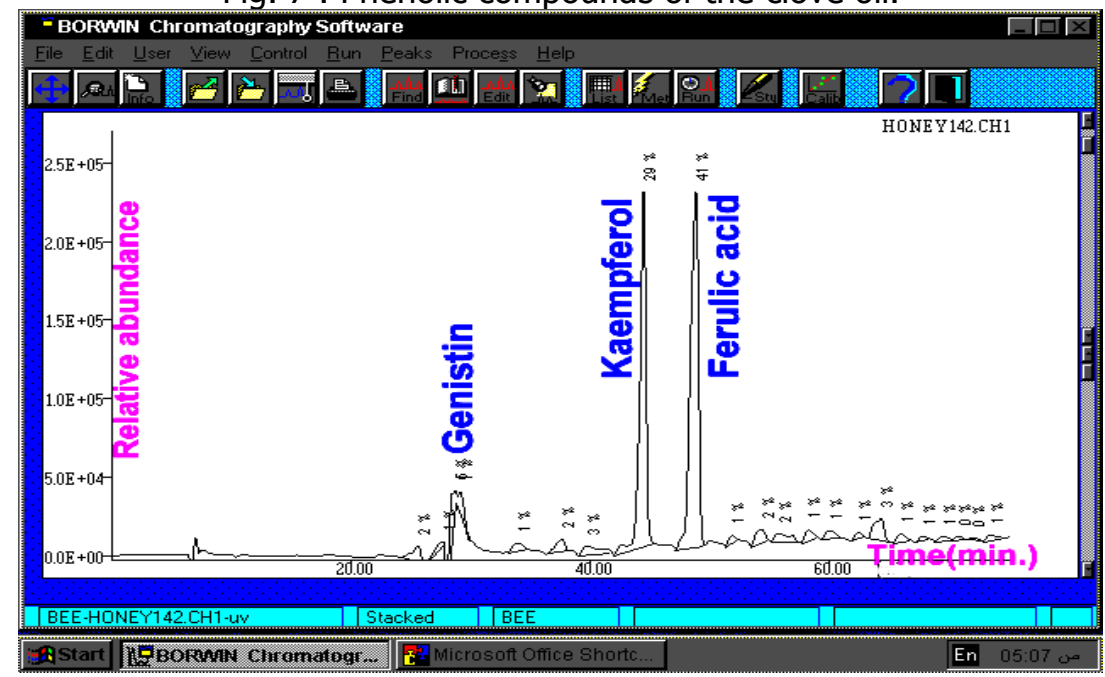

Fig.8: Phenolic compounds of the cumin oil.

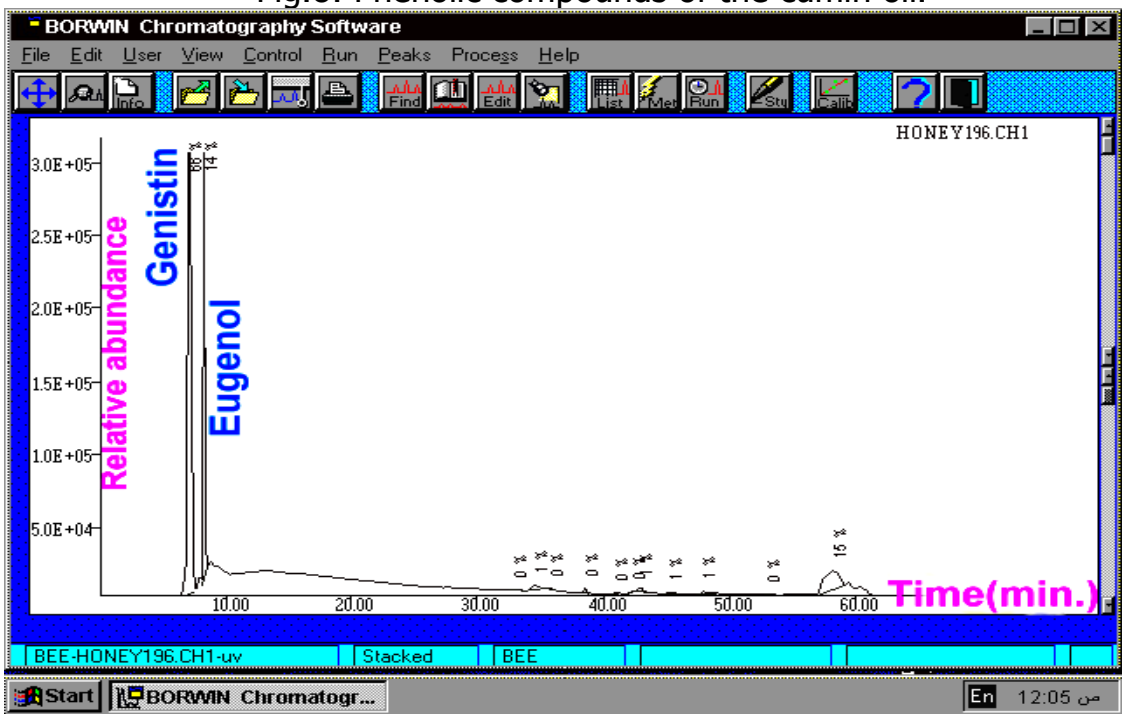

Fig. 9 : Phenolic compounds of the citrus oil. 


\section{REFERENCES}

1. Ali, BH and G. Blunden. 2003. Pharmacological and toxicological properties of Nigella sativa. Phytoter Res.,17(4):299-305.

2. Arici, M., F. A. n. Colak and Ü. Gecgel. 2007. Effect of gamma radiation on microbiological and oil properties of black Cumin (Nigella sativa L.) . Grasas Y. Aceites, 58 (4):339-343.

3. Bensky, D. S. C., E. Stoger and A. Gamble. 2004. Chinese Herbal Medicine: Materia Medica, Third Edition.

4. Forsgren, E., T. C. Olofsson, A. Vasquez and I. Fries. 2010. Probiotic bacteria in honey bee stomach inhibits pathogens. Apidologie, 41, 99-108.

5. Gende L. B., M. J. Eguaras and R. Fritz. 2008. Evaluation of culture media for Paenibacillus larvae applied to studies of antimicrobial activity. Revista Argentina de Microbiología, 40: 147-150.

6. Giersch T., I. Barchia and M. Hornitzky. 2009. Can fatty acids and oxytetracycline protect artificially raised larvae from developing European foulbrood?. Apidologie, 41, 2:151-159.

7. Gilliam, M. and H. Shimanuki, 1971. Blood cells of the worker honey bee. J. Apic. Res., 10 (2): 79-85.

8. Guan W., S. Li, R. Yan, S. Tang and C. Quan. 2007. Comparison of Aromatic oils of Clove buds extracted with supercritical carbon dioxide and other three traditional extraction methods. Food Chemistry., Vol.101, Issue 4:1558-1564

9. Hashish, M. EL Saied, 2008. Study on incidence of American and European foulbrood diseases at bee colonies and its relation with varroa mite. Msc. Thesis, Fac. of Agric. Moshtohor,Benha Univ. pp.141.

10. Jane Buckle, MA, RN., 2002 . Clinical Aromatherapy and AIDS. Journal of the Association of Nurses in AIDS care, Vol. 13, No. 3: 81-99.

11. Matheson, A. and M.Reid. 1992. Strategies for the prevention and control of American Foulbrood. Part I. American Bee J., 132: 399-402.

12. Oszmianski, J. and C. Y. Lee. 1990. Isolation and HPLC determination of phenolic compounds in red grapes. Am. J. Enol. Vitic. 41:3:204-206. 
13. Pourmortazavi, S. M., M. Ghadiri and S. S. Hajimirsadeghi.2005. Supercritical fluid extraction of volatile components from Bunium persicum Boiss. (black Cumin) and Mespilus germanica L. (medlar) seeds. Journal of Food Composition and Analysis,Vol. 18, Issue 5: 439-446

14. Riessberger, G. U., W. Von der Ohe and K. Crailsheim. 2001. Adult honey bee's resistance against Paenibacillus larvae larvae, the causative agent of the American Foulbrood. J. of Invertebr. Pathol. Vol. 77, Issue 4,: 231-236 .

15. Right, DA and JP. Payne. 1962. A clinical study of intravenous anaesthesia with a eugenol derivative, G. 29.505" (abstract). British Journal of Anaesthesia, 34: 379-385

16. Shimanuki, H. and D. A. Knox. 1991. Diagnosis of honey bee diseases. U. S., Agric. Res. Serv., Agric. Handbook ,No. AH-690, 53p 


\title{
تحمل طوائف نحل العل للإصابة بتعفن الحضنة الأمريكى بإستخدام الزيوت العطرية
}

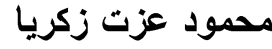 \\ معرج بحوث وقاية النباتات - مركز البحوث النزراعية- الدقى - الجبزة
}

تم دراسة قدرة تحمل طو ائف نحل العسل للإصابة بمرض تعفن الحضنة الأمريكى (AFB)

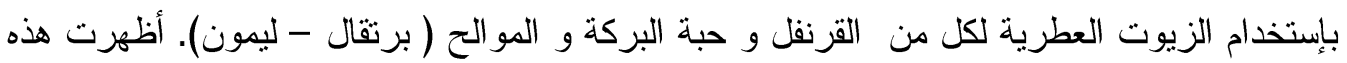

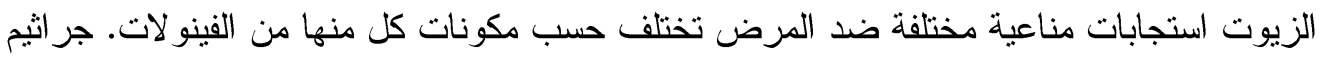

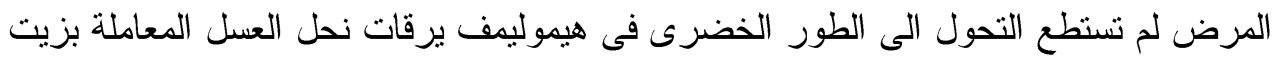
القرنفل و الذى يتميز بتعدد المركبات الفينولية عن غيره من الزيوت المختبرة . أدى ذلك إلى قلى لقدرة

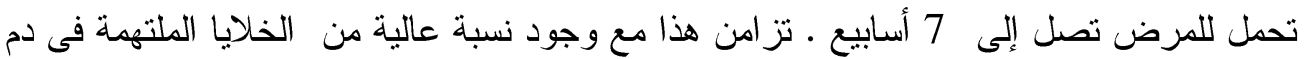
برقات النحل المتحملة للمرض. 